\title{
SOUTH COAST ABORIGINAL RESOURCE CENTRE - NOWRA
}

Dear Editor

I would like to introduce the South Coast Aboriginal Resource Centre to your readers.

The South Coast Aboriginal Resource Centre commenced as the result of meetings between members of the Nowra Aboriginal Community and a group of interested Nowra teachers. The group decided if Aboriginal studies was to be taught in schools, schools needed resource support to assist in developing units of work. The Centre would also support the implementation of the manadatory Aboriginal perspectives to existing curriculum.

The Centre was originally funded by the Norman Catts Trust and later by the Multicultural Co-ordinating Committee. I wish to express my sincere thanks to the Norman Catts Trust for showing foresight in funding a worthwhile project. Thanks also to the Multicultural Co-ordinating Committee for their ongoing funding up until the end of 1986.

The Centre does a great service for Aboriginal education in the South Coast Region. It is housed at Nowra High School and I am its co-ordinator.

Over the past five years the Resource Centre has acquired a large collection of resources catering for $k-12$, tertiary education, and teacher reference. It has a variety of books, pictures, posters, photographs, slides, records, cassettes, videos and artefacts. These resources are available to students, community and teachers. They can be borrowed for a period of 6 weeks / and 2 weeks (individuals).

Borrowing times: 12 noon - 3.30p.m. Wednesdays (if Wednesdays are unsuitable, other arrangements can be made by phoning Loretta (044) 214977.)

The Centre is in the process of collecting local material relating to Aborigines of the South Coast. If anyone has material that may be of use, please contact me.

To the editor and all involved in producing The Aboriginal Child at School, I look forward to reading articles published in a well informed Journal. Looking forward to the next edition.

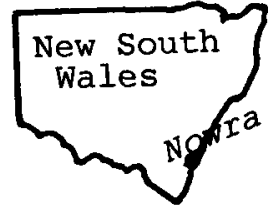

Mrs Loretta E. Parsley

Aboriginal Teaching Assistant

Nowra High School

P O BOX 183, NOWRA NSW 2541 